ANADOLU, J. of AARI

ISSN: 1300-0225 (Print)

E-ISSN: 2667-6087 (Online)

2019, 29 (1): 15-24

DOI: $10.18615 /$ anadolu. 568782

\title{
Gazal Boynuzu (Lotus corniculatus L.) Genotiplerinin Akdeniz İklim Koşullarında Verimlerinin Belirlenmesi
}

\author{
Hüseyin ÖZPINAR ${ }^{I^{*}} \quad$ Mustafa AVCI ${ }^{2}$ Ali Alptekin ACAR ${ }^{3} \quad$ Serhat AKSU ${ }^{4}$ \\ Firdevs NIKSARLI INAAL ${ }^{1} \quad$ Ergül AY ${ }^{1} \quad$ İker INAL ${ }^{5}$

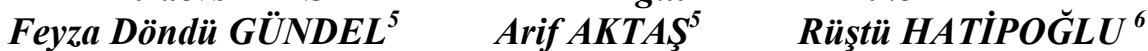 \\ ${ }^{1}$ Ege Tarımsal Araştırma Enstitüsü, İmir/TURKEY \\ ${ }^{2}$ Ömer Halisdemir Üniversitesi, Niğde/TURKEY \\ ${ }^{3}$ Manisa İl Tarım ve Orman Müdürlü̆ğ̈, Manisa/TURKEY \\ ${ }^{4} \dot{I}_{z m i r}$ İ Tarım ve Orman Müdürlü̆̆̈̈̈, Izmir/TURKEY \\ ${ }^{5}$ Doğu Akdeniz, Tarımsal Araştırma Enstitüsü, Adana/TURKEY \\ ${ }^{6}$ Çukurova Üniversitesi, Adana/TURKEY \\ *Corresponding author (Sorumlu yazar): huseyin_ozpinar@hotmail.com \\ Received (Geliş tarihi): 16.10.2018Ａccepted (Kabul tarihi): 12.02.2019
}

ÖZ: Proje, çeşit eksikliğini gidermeye katkı sağlamak için Ege Tarımsal Araştırma Enstitüsü’nde yurtiçi ve yurtdlşı kaynaklardan temin edilen, çok ylllk baklagil yem bitkilerinden gazal boynuzu türüne ait materyal üzerinde sürdürülen çalışmalar sonucu, ilk ıslah döngüsü tamamlanarak geliştirilen çeşit adaylarının İzmir ve Adana'da bölge verim denemelerine alınarak verim ve uyum performanslarını belirlenmesi amacı ile gerçekleştirilmiştir. Bölge verim denemeleri tesadüf blokları deneme deseninde çeşit adayları, kontrol çeşitler ve populasyon kullanılarak dört tekerrürlü olarak kurulmuştur. İzmir ve Adana lokasyonlarında iki yll yürütülen çalışmada; genotiplerin her iki lokasyon ve yıl ortalamalarına göre kuru madde verimlerinin 694-951 kg/da; NDF oranlarının \% 37,1-39,4; ADF oranlarının ise \% 29,8-31,2 olduğu belirlenmiştir. Tohum verimlerinin 9,723,4 kg/da; çimlenme oranlarının \% 52,3-67,9; 1000 tohum ă̆ırlıklarının 1,04-1,21 g arasında değiştiği saptanmıştır. Kuru madde ve tohum verimleri incelenen çeşit adayları ilk verim gruplarında yer alarak, yüksek verimli, Akdeniz iklim kuşağına uyumlu olduğu tespit edilmiștir.

Anahtar Kelimeler: Gazal boynuzu, islah, kuru madde verimi, tohum verimi, kalite, ADF, NDF.

\section{Determination of Yields of Bird's-foot Trefoil (Lotus corniculatus L.) Genotypes Under Mediterranean Climatic Conditions}

\begin{abstract}
This project was conducted to test performance of cultivar candidates of legume bird's-foot trefoil developed in the forage crop breeding program of Aegean Agricultural Research Institute after completing the first cycle of selection procedures whose base material had been obtained from domestic and foreign sources. Regional yield trials were arranged in randomized complete block design with four replications by using cultivar nominees, check cultivars and population at Izmir and Adana locations and conducted for two years in 2015 and 2016. According to mean yields of trials obtained as both locations and year means, genotypes obtained 6940-9510 kg/ha matter yields, 37.1-39.4\%, NDF rates and 29.8-31.2\%, ADF ratios while seed yields were 97-234 kg/ha, germination rates were 52.3-67.9\%, 1000 seed weights were 1.04-1.21 g. In terms of dry matter and seed yields, the trials showed that variety candidates were found to be high yielding and well adapted to the region, ranking in first yield groups.
\end{abstract}

Keywords: Bird's-foot trefoil, breeding, dry matter yield, seed yield, quality, $A D F, N D F$. 


\section{GíRiş}

Ülkemiz hayvancılığının farklı sorunları olmakla beraber, bu sorunlardan en önemlisini hayvanlarımızın potansiyellerine uygun şekilde beslenememesi oluşturmaktadır. Ülkemizde mevcut 16,4 milyon büyük baş birimi (BB) hayvanının gereksinimi olan yaklaşık 83,9 milyon ton kaliteli kaba yem yeterli miktarda sağlanamamaktadır (Özkan ve Demirbağ, 2016). Halen ülkemiz hayvancılığının en önemli kaba yem kaynağını 14,6 milyon ha alan kaplayan doğal meralar oluşturmaktadır. Toplam mera alanlarının \%5,49'u Ege Bölgesi'nde, $\% 4,62$ 'si de Akdeniz Bölgesi'nde bulunmaktadır (Anonim, 2001a).

Ancak, mülkiyeti devlete, kullanım hakkı bulundukları yerleşim yeri halkına ait olan bu doğal kaynaklarımızın uzun yıllardan beri süre gelen tekniğine uygun olmayan kullanım sonucu bitki örtülerini büyük ölçüde kaybetmiş ve verimleri son derece düşmüş durumdadır. Bundan dolayı mera alanlarımızın önemli kısmının yeniden bitkilendirme ile ıslahına ihtiyaç duyulmaktadır. Böylelikle, meraların 1slahında kullanılacak farklı ekolojik koşullara uyumlu yüksek verimli ve kaliteli ot sağlayan yem bitkisi çeşitlerinin geliştirilmesi ve bunların tohumlarının yeterli miktarda üretilmesi gerekmektedir.

Doğal meraların ıslahında kullanılan çok yıllık bir baklagil yem bitkisi olan gazal boynuzu aynı zamanda toprak ıslahında ve erozyon kontrolünde de önemli rol oynamaktadır. Birçok baklagil yem bitkisine göre kışa daha dayanıklı, asit topraklarda verimli, tuza oldukça dayanıklı olan gazal boynuzu Akdeniz havzasının doğal bir türüdür. Gazal boynuzunun köklerinin yana doğru yayılımı daha fazla olduğundan yüzeysel topraklara, su basmalarına dayanıklı, ot kalitesi yüksektir ve aynı zamanda şişmeye neden olmamaktadır (Chriansen-Weiger ve ark., 1979; Frame ve ark., 1998; Sardaro ve ark., 2008).

Karadağ ve ark. (2016)'nın Tokat-Kazova koşullarında bazı çok yıllık yembitkilerinin verim ve kalitelerini belirlemeyi amaçladıkları çalışmalarında 3 gazal boynuzu genotipinin kuru madde verimlerinin 1250-1466,2 $\mathrm{kg} / \mathrm{da}$; tohum verimlerinin $28-34,7 \mathrm{~kg} / \mathrm{da} ; \quad 1000$ tohum ağırlıklarının 1,157-1,173 g; ham protein oranlarının \%18,94-19,76; ADF oranlarının \%3032,30; NDF oranlarının \%39,20-41,80 arasında değiştiğini belirlemişlerdir. Çınar ve ark. (2016) ise aynı genotiplerin Sivas ekolojik koşullarında kuru madde verimlerini 505,3-592 kg/da; tohum verimlerini 24,3-28,7 kg/da; 1000 tane ağırlıklarını 0,95-1,05 g; ADF oranlarını \% 31,1-32,6; NDF oranlarını \%39,9-42,0 olarak bildirmişlerdir. Churkova (2007) Bulgaristan'da yaptığı 3 yıllık çalışmada farklı karışımlar ve yalın olarak ektiği gazal boynuzu tohum verimini ortalama $25,8 \mathrm{~kg} / \mathrm{da}$ olarak bildirmiştir.

Çok yıllık baklagil ve buğdaygil yem bitkilerinin 1slahında çoğunlukla ve özellikle sslahın ilk döngülerinde fenotipe dayalı tekrarlamalı seleksiyon yöntemleri izlenmektedir (Knowles, 1977; Poehlman, 1987; Poehlman ve Sleeper, 1995; Casler ve ark., 2003; Marshall ve Wilkins, 2003; Sabancı ve Tosun, 2009).

$\mathrm{Bu}$ araştırmada gazal boynuzu türünde geliştirilen ETAE GB-1 ve ETAE GB-2 genotiplerinin Akdeniz iklim koşullarında performanslarının belirlenmesi amaçlanmıştır.

\section{MATERYAL VE METOT}

Bölge verim denemeleri, ot ve tohum verimlerini belirlemek amacıyla iki ayrı deneme şeklinde tesadüf blokları deneme desenine göre 4 tekrarlamalı olarak kurulmuş̧tur. Parsel büyüklüğü 2,5 $\mathrm{m} \times 5 \mathrm{~m}=12,5 \mathrm{~m}^{2}$ olarak, 10 siralı ve sira aras1 $25 \mathrm{~cm}$ olacak şekilde düzenlenmiştir. ETAE GB- 1 ve ETAE GB-2 kodlarıyla çeşit adaylarımızın tohumlar1; Leo ve Gaida çeşitleri ile Tokat populasyonu standart olarak kullanılarak İzmir'de 06.11.2014, Adana lokasyonunda ise 10.11.2014 tarihlerinde olmak üzere dekara $1,0 \mathrm{~kg}$ tohumluk kullanılarak ekilmiştir. Tesis yılında $3 \mathrm{~kg} / \mathrm{da}$ saf azot amonyum sülfat, $10 \mathrm{~kg} / \mathrm{da}$ saf fosfor $\left(\mathrm{P}_{2} \mathrm{O}_{5}\right)$ triple süper fosfat gübresi şeklinde, bakım yıllarında ise $10 \mathrm{~kg}$ saf fosfor $\left(\mathrm{P}_{2} \mathrm{O}_{5}\right)$ triple süper fosfat gübresi şeklinde verilmiştir. Parsellerde gerektiği durumlarda yabancı ot mücadelesi yapılmıştır. Parseller bitkilerin su ihtiyaçlanı olduğunda yağmurlama ile sulanmıştır. Yeşil ot hasatları paresellerin \%10 çiçeklenme zamanında gerçekleştirilmiştir. İzmir lokasyonunda her iki senede Leo çeşidinde 3 biçim, diğer genotiplerde ise 5 biçim yapılmıştır (Çizelge 1). Adana lokasyonunda ise her yıl her 
H. ÖZPINAR, M. AVCI, A. A. ACAR, S. AKSU, F. NIKSARLI İNAL, E. AY, İ. İNAL, F. D. GÜNDEL, A. AKTAŞ, R. HATIPOĞLU: GAZAL BOYNUZU (Lotus cornıculatus L.) GENOTIPLERININ AKDENIZ İKLIM KOŞULLARINDA VERIMLERININ BELIRLENMESI

genotipte üç biçim yapılmıştır (Çizelge 2). İzmir lokasyonu araştırma alanında Menemen ovası Gediz tını (typic Ustorthent) topraklar hakimdir ve $\% 1,28$ organik madde içeriğine sahiptir. Adana lokasyonu araştırma alanının toprakları ise Seyhan nehrinin taşkınlarıyla getirilip depolanan ince tekstürlü, yaşlı nehir terası toprakları olup, Arıklı serisindendir ve $\% 1,7$ organik madde içermektedir.

İzmir lokasyonunda yıllık yağış toplamları 2015 y1lında $683 \mathrm{~mm}$ ile uzun yıllar ortalamasından (530 $\mathrm{mm}$ ) daha yüksek, 2016 yılında ise 481,6 mm ile daha düşük bulunmuştur. Ortalama sicaklıklar 2015 ve 2016 yilinda sirasiyla $17,2{ }^{\circ} \mathrm{C}$ ve $18,1^{\circ} \mathrm{C}$ gerçekleşerek, uzun yıllar ortalamasından $\left(16,9^{\circ} \mathrm{C}\right)$ daha yüksek bulunmuştur. Minimum sicakliklar 2015 y1linda $-5,4{ }^{\circ} \mathrm{C}, 2016$ yilinda $-3,8{ }^{\circ} \mathrm{C}$ ile uzun y1llar değerinden $\left(-7,4{ }^{\circ} \mathrm{C}\right)$ daha düşük gerçekleşmiştir. Maksimum sicakliklar da 2015 ve 2016 yilında siras ile $38,7^{\circ} \mathrm{C}$ ve $41,4{ }^{\circ} \mathrm{C}$ bulunarak uzun yillara göre $\left(44,1{ }^{\circ} \mathrm{C}\right)$ daha düşük gerçekleşmiştir (Anonim, 2016).

Adana lokasyonunda yıllık yağış toplamları 2015 y1lında $471 \mathrm{~mm}, 2016$ y1lında ise $363 \mathrm{~mm}$ olmuştur. Her iki yılda da yağış toplamı uzun yıllar ortalaması olan 655 mm'nin altında gerçekleşmiştir. Adana lokasyonunda ortalama sicakliklar hem 2015 yılinda $19,4{ }^{\circ} \mathrm{C}$ hem de 2016 yilında $19,4{ }^{\circ} \mathrm{C}$ gerçekleşerek uzun yıllar ortalamasına $\left(19,0{ }^{\circ} \mathrm{C}\right)$ çok yakın seyretmiştir. Minimum sıcaklıklar 2015 y1linda $-3,0 \quad{ }^{\circ} \mathrm{C}, 2016$ y1linda ise $\quad-8,0 \quad{ }^{\circ} \mathrm{C}$ gerçekleşmiştir. Uzun yılların minimum sıcaklığ 1 $8,1{ }^{\circ} \mathrm{C}$ 'dir. 2015 yılı maksimum sicaklı $\breve{g}_{1} 42,0{ }^{\circ} \mathrm{C}$, 2016 yıl1 ise $41,0{ }^{\circ} \mathrm{C}^{\prime}$ dir. Maksimum sicaklıklar uzun yıllara göre $\left(44,0{ }^{\circ} \mathrm{C}\right)$ daha düşük oluşmuştur.

\section{Araştırmada incelenen özellikler}

\section{Agronomik özellikler}

Hasattan sonra parsellerin yaş ot ağırlıkları tartılmış, yeşil ot içinden rastgele alınan $0,5 \mathrm{~kg}$ ' $11 \mathrm{k}$ örnekler kurutma dolabında 48 saat $65{ }^{\circ} \mathrm{C}$ ' de kurutularak kuru madde oranları saptanmıştır. Kuru madde oranı değerlerinden yararlanılarak kuru madde verimi $(\mathrm{kg} / \mathrm{da})$ hesaplanmıştır. Biçimler toplanarak genotiplerin y1llık toplam kuru maddeleri hesaplanmıştır. Fizyolojik olumu tamamlanan parseller elle hasat edilmiştir. Hasat edilen parseller laboratuar harman makinasıly dövülmüş, elekten geçirilmiş ve temizlenmiştir. Tohum verimi \%14 düzeltme faktörü kullanılarak dekara çevrilmiştir (Anonim, 2001b). Bin tane ağırlığı temizlenmiş tohumlardan 4 tekerrürlü olarak 100'er tane sayılip, tartılarak ortalamas1 alınmıştır (Soya ve ark., 2005). Çimlenme oranı Ellis ve ark. (1985)'na göre 3 tekerrürlü olarak 50 tane tohumdan çimlenen tohumların sayılıp ortalaması alınarak \% olarak ifade edilmiştir.

Çizelge 1. Gazal boynuzu genotiplerinin İzmir lokasyonu biçim zamanları (2015-2016).

Table 1. Cutting time of bird's-foot trefoil genotypes in Izmir (2015-2016).

\begin{tabular}{|c|c|c|c|c|c|c|c|c|c|c|}
\hline \multirow{2}{*}{$\begin{array}{l}\text { Genotipler } \\
\text { Genotypes }\end{array}$} & \multicolumn{5}{|c|}{$\begin{array}{l}\text { Biçim zamanları (2015) } \\
\text { Cutting time (2015) }\end{array}$} & \multicolumn{5}{|c|}{$\begin{array}{c}\text { Biçim zamanları (2016) } \\
\text { Cutting time (2016) }\end{array}$} \\
\hline & 1 & 2 & 3 & 4 & 5 & 1 & 2 & 3 & 4 & 5 \\
\hline ETAE GB 1 & 25.05 & 15.06 & 14.07 & 14.08 & 20.10 & 29.04 & 26.05 & 16.06 & 01.07 & 22.07 \\
\hline ETAE GB 2 & 25.05 & 15.06 & 14.07 & 14.08 & 20.10 & 29.04 & 26.05 & 16.06 & 01.07 & 22.07 \\
\hline Tokat populasyonu & 25.05 & 15.06 & 14.07 & 14.08 & 20.10 & 29.04 & 26.05 & 16.06 & 01.07 & 22.07 \\
\hline Leo & 15.06 & 14.07 & 14.08 & - & - & 03.06 & 28.06 & 22.07 & - & - \\
\hline Gaida & 25.05 & 15.06 & 14.07 & 14.08 & 20.10 & 29.04 & 26.05 & 16.06 & 01.07 & 22.07 \\
\hline
\end{tabular}

Çizelge 2. Gazal boynuzu genotiplerinin Adana lokasyonu biçim zamanları(2015-2016).

Table 2. Cutting time of bird's-foot trefoil genotypes in Adana (2015-2016).

\begin{tabular}{|c|c|c|c|c|c|c|}
\hline \multirow{2}{*}{$\begin{array}{l}\text { Genotipler } \\
\text { Genotypes }\end{array}$} & \multicolumn{3}{|c|}{$\begin{array}{c}\text { Biçim zamanları (2015) } \\
\text { Cutting time }(2015)\end{array}$} & \multicolumn{3}{|c|}{$\begin{array}{c}\text { Biçim zamanları (2016) } \\
\text { Cutting time }(2016)\end{array}$} \\
\hline & 1 & 2 & 3 & 1 & 2 & 3 \\
\hline ETAE GB 1 & 16.04 & 22.09 & 13.11 & 09.04 & 12.10 & 28.10 \\
\hline ETAE GB 2 & 16.04 & 22.09 & 13.11 & 09.04 & 12.10 & 28.10 \\
\hline Tokat populasyonu & 16.04 & 22.09 & 13.11 & 09.04 & 12.10 & 28.10 \\
\hline Leo & 28.04 & 11.09 & 01.11 & 11.04 & 14.10 & 28.10 \\
\hline Gaida & 16.04 & 22.09 & 13.11 & 09.04 & 12.10 & 28.10 \\
\hline
\end{tabular}


Kalite analizleri: Parsellerden alınan bitki örnekleri $65^{\circ} \mathrm{C}$ 'ye ayarlanmış etüvde, ağırlıkları sabitleşinceye kadar kurutulmuştur. $\mathrm{Bu}$ örnekler kalite analizleri için $1 \mathrm{~mm}$ 'lik elekten geçecek şekilde ögütüldükten (Brabender Ohg Duisburg) sonra örneklerde kalite analizleri yapılmıştır.

Kuru madde örneklerinde yarı otomatik Tekatör marka Kjeldahl cihazıyla azot tayini yapılmıștır. Belirlenen azot değerleri 6,25 dönüşüm katsayısı ile çarpılarak söz konusu ot örneğindeki \% ham protein değerleri saptanmıştır (Anonymous, 1995). Bitki hücre duvarındaki selüloz ve lignin miktarı, "\% ADF (Acid Detergent Fiber / Asit Deterjanda Çözünmeyen Lif)", selüloz, hemiselüloz ve lignin miktar1 “\% NDF (Neutral Detergent Fiber / Nötr Deterjanda Çözünmeyen Lif)" Van Soest ve ark. (1991) tarafindan belirtilen esaslara göre ANKOM lif analiz cihazı (Fiber analizer) ile belirlenmiştir.

Araştırmada elde edilen verilerin değerlendirilmesi: Araştırma ile ilgili tarla denemelerinden ve laboratuvar analizinden elde edilen verilerin JMP istatistik paket program1 kullanılarak (birden fazla y1l ve her y1l aynı yerlerde ve aynı randomizasyonla yürütülen-çakılı denemeler veya çok yıllık bitkiler modeli) varyans analizleri yapılmıştır (Steel ve Torrie, 1980; Yurtsever, 1984).

\section{BULGULAR VE TARTIŞMA}

\section{Kuru madde verimi}

Kuru madde verimi açısından; yıl, genotip ve lokasyon istatistiki olarak önemli yıl x lokasyon, genotip x lokasyon ve y1l x lokasyon x genotip interaksiyonları ise önemsiz bulunmuştur (Çizelge 3). Adana lokasyonu daha yüksek verime sahip olmuştur. 2016 y1lı verim ortalaması 2015 y1l ortalamasından daha yüksek bulunmuștur. Genotipler açısından ise, aday genotipler ile Gaida kontrol çeşidi ilk verim grubunu oluşturmuşlardır. Leo kontrol çeşidi ise lokasyonlarda düşük verime sahip olarak son verim grubunda yer almıştır. Genotip $\mathrm{x}$ lokasyon interaksiyonun önemli bulunmaması genotiplerin performanslarının lokasyona bağlı olmadığını göstermiştir.

Kuru madde verimleri açisından deneme bulgularımız Çınar ve ark. (2016)'nın çalışmasından elde edilen sonuçlardan $(505,3-592 \mathrm{~kg} / \mathrm{da})$ daha yüksek, Bologna ve ark. (1996)'nın (1022,4 kg/da) ve Karadağ ve ark. (2016)'nın. (1250-1466,2 $\mathrm{kg} / \mathrm{da}$ ) sonuçlarından daha düşük bulunmuştur. Marley ve ark. (2006) yaptıkları çalışmada kullandıkları genotiplerin verim ortalamalarının çok farklılıklar gösterdiğini belirlemişlerdir. Çeşit adaylarının lokasyonlarda yüksek verime sahip olması Akdeniz iklim kuşağı için uyumlu çeşitler olduğunu da göstermektedir.

Çizelge 3. Gazal boynuzu genotiplerinin kuru madde verimleri $(\mathrm{kg} / \mathrm{da})$.

Table 3. Dry matter yields of bird's-foot trefoil genotypes (kg/da).

\begin{tabular}{|c|c|c|c|c|c|c|c|c|}
\hline \multirow[t]{2}{*}{ Genotipler / Genotypes } & & \multicolumn{3}{|c|}{$\begin{array}{c}\text { İzmir lokasyonu } \\
\text { Izmir location }\end{array}$} & \multicolumn{3}{|c|}{$\begin{array}{l}\text { Adana lokasyonu } \\
\text { Adana location }\end{array}$} & \multirow{2}{*}{$\begin{array}{l}\text { Genel ort. } \\
\text { Gen. mean }\end{array}$} \\
\hline & & 2015 & 2016 & Ort./mean & 2015 & 2016 & Ort./mean & \\
\hline ETAE GB-1 & & 669 & 1178 & 923 & 707 & 1253 & 980 & $951 \mathrm{~A}$ \\
\hline ETAE GB-2 & & 697 & 1208 & 952 & 712 & 1112 & 912 & $932 \mathrm{~A}$ \\
\hline Tokat populasyonu & & 585 & 1035 & 810 & 632 & 1134 & 883 & $846 \mathrm{~B}$ \\
\hline Leo & & 633 & 704 & 669 & 741 & 698 & 720 & $694 \mathrm{C}$ \\
\hline Gaida & & 641 & 1159 & 900 & 696 & 1261 & 978 & $939 \mathrm{~A}$ \\
\hline Lokasyon / Location & * & & & $851 \mathrm{~b}$ & & & $894 \mathrm{a}$ & \\
\hline Y1l / Year & $* * *$ & $671 \mathrm{~b}$ & $1074 \mathrm{a}$ & & & & & \\
\hline Genotip / Genotype & $* * *$ & & & & & & & \\
\hline Genotip x Lokasyon & Ö.D & & & & & & & \\
\hline Y1l x Lok. / Year x Loc. & Ö.D & 645 & 1057 & & 697 & 1092 & & \\
\hline Y1l x Lok. x Gen/Year x Lo..x Gen. & Ö.D & & & & & & & \\
\hline \multicolumn{9}{|c|}{ LSD $(0,05)$ : Genotip / Genotype: 81,43; Lokasyon / Location: 29,15; Y1l / Year: 87,12 } \\
\hline $\mathrm{CV}(\%)$ & & & & & & & & 8,58 \\
\hline
\end{tabular}


H. ÖZPINAR, M. AVCI, A. A. ACAR, S. AKSU, F. NIKSARLI İNAL, E. AY, İ. İNAL, F. D. GÜNDEL, A. AKTAŞ, R. HATIPOĞLU: GAZAL BOYNUZU (Lotus corniculatus L.) GENOTIPLERININ AKDENIZ IKLIM KOŞULLARINDA VERIMLERININ BELIRLENMESI

\section{Kalite Özellikleri}

\section{Ham protein oranı}

Yapılan değerlendirmede; lokasyon, y1l, genotip, genotip x lokasyon, yıl x lokasyon interaksiyonları istatistiksel olarak önemli, y1l x genotip x lokasyon interaksiyonu ise önemsiz bulunmuş̧ur.

İzmir lokasyonunda ham protein oran1 ortalamas1 $(\% 18,6)$ Adana lokasyonu ortalamasina göre $(\% 14,4)$ daha yüksek bulunmuştur (Çizelge 4). Araştırmada 2015 yılında saptanan ortalama ham protein oran1 $(\% 18,3) 2016$ y1lında tespit edilen orandan $(\% 14,7)$ daha yüksek gerçekleşmiştir. Genotiplerin ham protein oranlar1 \%15,9-17,5 arasında değişmiş ve Loe çeşidi en yüksek oran ile ilk sırada yer almış ve araştırmada yer alan diğer genotiplerden önemli derecede farklı bulunmamış ve düşük verim grubunda yer almışlardır. Ham protein oranı değerleri Karadağ ve ark. (2016) $(\% 18,94-19,76)$ ve Çınar ve ark. (2016)'nın (\% 18,4-18,8) Tokat ve Sivas koşullarında yürüttükleri çalışmalarından elde ettikleri sonuçlardan daha düşük bulunmuştur.

\section{NDF oranı}

Yapılan değerlendirmede; lokasyon, y1l, y1l $\mathrm{x}$ lokasyon, y1l x genotip x lokasyon interaksiyonu istatistiksel olarak önemli bulunurken, genotip ve genotip x lokasyon interaksiyonları ise önemsiz bulunmuştur.

İzmir lokasyonunda NDF oran1 ortalamas1 $(\% 36,5)$ Adana lokasyonu ortalamasına göre $(\% 39,9)$ daha düşük bulunmuştur. Araştırmada 2015 yılında saptanan ortalama NDF oranı $(\% 36,5) 2016$ y1lında tespit edilen orandan $(\% 40,0)$ daha düşük bulunmuştur (Çizelge 5). Genotiplerin NDF oranlar1 \%37,1-39,4 arasında değişmiştir. Denemede yer alan Gaida kontrol çeşidinin 2015 yılında İzmir lokasyonundaki NDF oranı diğer genotiplerin oranlarına yakın veya benzer bir değer $(\% 31,6)$ göstermesine ragmen, bu çeşidin aynı yıl Adana lokasyonundaki NDF oranı araştırmada yer alan diğer genotiplerden daha yüksek $(\% 44,1)$ bulunmuştur. Bu gibi değişkenlikler y1l $\mathrm{x}$ genotip $\mathrm{x}$ lokasyon interaksiyonunun ortaya çıkmasında etkili olmuştur. NDF oranı değerleri, Tokat ve Sivas koşullarında, Karadağ ve ark. (2016) $(\% 39,20-41,80)$ ile Çınar ve ark. (2016)'nın $(\% 39,9-42,0)$ yürüttükleri çalıșmalarından elde ettikleri sonuçlara benzerlik göstermektedir.

Çizelge 4. Gazal boynuzu genotiplerinin ham protein oranları (\%).

Table 4. Protein rates of bird's-foot trefoil genotypes (\%).

\begin{tabular}{|c|c|c|c|c|c|c|c|c|}
\hline \multirow[t]{2}{*}{ Genotipler / Genotypes } & & \multicolumn{3}{|c|}{$\begin{array}{l}\text { İzmir lokasyonu } \\
\text { Izmir location }\end{array}$} & \multicolumn{3}{|c|}{$\begin{array}{l}\text { Adana lokasyonu } \\
\text { Adana location }\end{array}$} & \multirow{2}{*}{$\begin{array}{l}\text { Genel ort. } \\
\text { Gen. mean }\end{array}$} \\
\hline & & 2015 & 2016 & Ort./mean & 2015 & 2016 & Ort./mean & \\
\hline ETAE GB-1 & & 14,7 & 21,2 & $18,0 \quad \mathrm{~B}$ & 13,1 & 14,7 & $13,9 \quad \mathrm{D}$ & $15,9 \quad \mathrm{~B}$ \\
\hline ETAE GB-2 & & 15,3 & 21,4 & $18,4 \quad \mathrm{AB}$ & 13,1 & 14,7 & $13,9 \quad \mathrm{D}$ & $16,1 \quad \mathrm{~B}$ \\
\hline Tokat populasyonu & & 15,3 & 21,5 & $18,3 \quad \mathrm{~B}$ & 14,3 & 14,8 & $14,6 \mathrm{D}$ & $16,4 \mathrm{~B}$ \\
\hline Leo & & 16,2 & 21,3 & $18,9 \quad \mathrm{AB}$ & 15,3 & 16,9 & $16,1 \mathrm{C}$ & $17,5 \mathrm{~A}$ \\
\hline Gaida & & 17,3 & 21,5 & $19,4 \mathrm{~A}$ & 12,6 & 15,0 & $13,8 \quad \mathrm{D}$ & $16,6 \quad \mathrm{~B}$ \\
\hline Lokasyon / Location & $* * *$ & & & $18,6 \mathrm{a}$ & & & $14,4 \mathrm{~b}$ & \\
\hline Y1l / Year & $* * *$ & $18,3 \mathrm{a}$ & $14,7 \mathrm{~b}$ & & & & & \\
\hline Genotip / Genotype & $* * *$ & & & & & & & 6,16 \\
\hline Genotip x Lokasyon & $* *$ & & & & & & & \\
\hline Y1l x Lok. / Year x Loc. & $* * *$ & $15,8 \mathrm{~b}$ & $21,4 \mathrm{a}$ & & $13,7 \mathrm{c}$ & $15,2 \mathrm{~b}$ & & \\
\hline Yil x Lok. x Gen/Year x Lo..x Gen. & Ö.D. & & & & & & & \\
\hline \multicolumn{9}{|c|}{$\begin{array}{l}\text { LSD (0,05): Genotip / Genotype 0,51; Lokasyon / Location: 0,45; Y1l / Year: 0,32; } \\
\text { Genotip.x Lokasyon / Genotype x Location: 0,88; Y1l x Lokasyon / Year x Location: } 0,55\end{array}$} \\
\hline CV $(\%)$ & & & & & & & & 7,5 \\
\hline
\end{tabular}


Çizelge 5. Gazal boynuzu genotiplerinin NDF oranları (\%).

Table 5. NDF rates of bird's-foot trefoil genotypes (\%).

\begin{tabular}{|c|c|c|c|c|c|c|c|c|}
\hline \multirow[t]{2}{*}{ Genotipler / Genotypes } & \multicolumn{4}{|c|}{$\begin{array}{l}\text { İzmir lokasyonu } \\
\text { Izmir location }\end{array}$} & \multicolumn{3}{|c|}{$\begin{array}{c}\text { Adana lokasyonu } \\
\text { Adana location }\end{array}$} & \multirow{2}{*}{$\begin{array}{l}\text { Genel ort. } \\
\text { Gen. mean }\end{array}$} \\
\hline & & 2015 & 2016 & Ort./mean & 2015 & 2016 & Ort./mean & \\
\hline ETAE GB-1 & & $30,7 \mathrm{~h}$ & $42,5 \mathrm{ac}$ & 36,6 & 41,3 be & $38,8 \mathrm{dg}$ & 40,1 & 38,3 \\
\hline ETAE GB-2 & & $31,0 \mathrm{~h}$ & 41,4 be & 36,2 & $42,0 \mathrm{ad}$ & $37,4 \mathrm{fg}$ & 39,7 & 37,9 \\
\hline Tokat populasyonu & & $31,2 \mathrm{~h}$ & 38,0 eg & 34,6 & 41,0 bf & $31,2 \mathrm{dg}$ & 39,7 & 37,1 \\
\hline Leo & & $32,3 \mathrm{~h}$ & 41,4 be & 36,8 & $39,5 \mathrm{cg}$ & $32,3 \mathrm{cg}$ & 39,0 & 38,3 \\
\hline Gaida & & $31,6 \mathrm{~h}$ & $45,0 \mathrm{a}$ & 38,4 & $44,1 \mathrm{ab}$ & $36,7 \quad \mathrm{~g}$ & 40,4 & 39,4 \\
\hline Lokasyon / Location & $* * *$ & & & $36,5 \mathrm{~b}$ & & & $39,9 \mathrm{a}$ & \\
\hline Y1l / Year & $* * *$ & $36,5 \mathrm{~b}$ & $40,0 \mathrm{a}$ & & & & & \\
\hline Genotip / Genotype & Ö.D & & & & & & & \\
\hline Genotip x Lokasyon & Ö.D & & & & & & & \\
\hline $\begin{array}{l}\text { Y1l x Lok. / Year x Loc. } \\
\text { Y1l x Lok. x Gen/Year x Lo..x Gen. }\end{array}$ & $\begin{array}{l}* * * \\
* *\end{array}$ & $31,4 \mathrm{c}$ & $41,7 \mathrm{a}$ & & $41,6 \mathrm{a}$ & $38,3 \mathrm{~b}$ & & \\
\hline $\begin{array}{ll}\operatorname{LSD}(0,05): & \text { Lokasyon / Locatio } \\
& \text { Y1l x Lokasyon x Ge }\end{array}$ & $\begin{array}{l}1,14 \\
\text { otip }\end{array}$ & $\begin{array}{l}\text { Yil / Ye } \\
\text { Year x I }\end{array}$ & $\begin{array}{l}7 \text {; Y } 11 \mathrm{x} \\
\text { on x Gen }\end{array}$ & $\begin{array}{l}\text { asyon / Ye } \\
\text { ge: } 2,66\end{array}$ & ocation: 1,60 & & & \\
\hline CV (\%) & & & & & & & & 6,67 \\
\hline
\end{tabular}

**, ***: $\mathrm{P}<0,01 ; \mathrm{P}<0,001$ düzeyinde önemli. Aynı harfle gösterilen ortalamalar arasında önemli fark yoktur.

**, ***: Significant at $\mathrm{P}<0.01 ; \mathrm{P}<0.001$. Same letters in a column are not significantly different.

Ö.D. Önemli değil (Non-significant).

\section{ADF oranı}

ADF oranı açısından yapılan değerlendirmede; lokasyon ve y1l istatistiksel olarak önemli bulunurken, genotip, genotip x lokasyon, y1l x lokasyon ve y1l x genotip $\mathrm{x}$ lokasyon interaksiyonları ise önemsiz bulunmuştur. İzmir lokasyonunda ADF oranı ortalaması $(\% 27,4)$ Adana lokasyonu ortalamasina göre $(\% 33,3)$ daha düşük bulunmuştur. Araştırmada 2015 y1lında saptanan ortalama ADF oran1 $(\% 31,3) 2016$ y1lında tespit edilen orandan
$(\% 29,4)$ daha düşük bulunmuştur (Çizelge 6). Gazal boynuzu genotiplerinin ADF oranları \%29,8-30,4 arasında değişmiştir. ADF oran1 değerleri, Tokat ve Sivas koşullarında, Karadağ ve ark. (2016) (\%30-32,30) ile Çınar ve ark. (2016)'nın $\quad(\% 29,8-31,2) \quad$ yürüttükleri çalışmalardan elde ettikleri sonuçlara benzerlik göstermektedir.

Çizelge 6. Gazal boynuzu genotiplerinin ADF oranları (\%).

Table 6 . ADF rates of bird's-foot trefoil genotypes (\%).

\begin{tabular}{|c|c|c|c|c|c|c|c|c|}
\hline \multirow[t]{2}{*}{ Genotipler / Genotypes } & \multicolumn{4}{|c|}{$\begin{array}{l}\text { İzmir lokasyonu } \\
\text { Izmir location }\end{array}$} & \multicolumn{3}{|c|}{$\begin{array}{c}\text { Adana lokasyonu } \\
\text { Adana location }\end{array}$} & \multirow{2}{*}{$\begin{array}{l}\text { Genel ort. } \\
\text { Gen.mean }\end{array}$} \\
\hline & & 2015 & 2016 & Ort./mean & 2015 & 2016 & Ort./mean & \\
\hline ETAE GB-1 & & 27,8 & 27,4 & 27,6 & 35,4 & 31,0 & 33,2 & 30,4 \\
\hline ETAE GB-2 & & 28,0 & 27,0 & 27,5 & 34,5 & 32,0 & 33,2 & 30,4 \\
\hline Tokat populasyonu & & 27,3 & 25,9 & 26,6 & 34,5 & 32,8 & 33,6 & 30,1 \\
\hline Leo & & 29,1 & 26,4 & 27,7 & 31,2 & 32,3 & 31,8 & 29,8 \\
\hline Gaida & & 28,4 & 26,8 & 27,6 & 37,1 & 32,5 & 34,8 & 31,2 \\
\hline Lokasyon / Location & $* * *$ & & & $27,4 \mathrm{~b}$ & & & $33,3 \mathrm{a}$ & \\
\hline Y1l / Year & $* * *$ & $31,3 \mathrm{a}$ & $29,4 \mathrm{~b}$ & & & & & \\
\hline Genotip / Genotype & Ö.D. & & & & & & & \\
\hline Genotip x Lokasyon & Ö.D. & & & & & & & \\
\hline Yil x Lok. / Year x Loc. & Ö.D. & 28,1 & 26,7 & & 34,5 & 32,1 & & \\
\hline Yil x Lok. x Gen/Year x Lo..x Gen. & Ö.D. & & & & & & & \\
\hline LSD $(0,05): \quad$ Lokasyon / Locati & on: 0,9 & $\mathrm{Y} 1 \mathrm{l} / \mathrm{Ye}$ & & & & & & \\
\hline $\mathrm{CV}(\%)$ & & & & & & & & 6,85 \\
\hline
\end{tabular}


H. ÖZPINAR, M. AVCI, A. A. ACAR, S. AKSU, F. NIKSARLI İNAL, E. AY, İ. İNAL, F. D. GÜNDEL, A. AKTAŞ, R. HATIPOĞLU: GAZAL BOYNUZU (Lotus corniculatus L.) GENOTIPLERININ AKDENIZ İKLIM KOŞULLARINDA VERIMLERININ BELIRLENMESI

Araştırmada incelenen genotipler kalite özellikleri açısından değerlendirildiklerinde ETAE GB-1 ve GB-2 genotipleri araştırmada kontrol olarak yer alan çeşitlere göre NDF ve ADF oranları yönünden benzerlik göstermekle birlikte, ham protein oranı açısından Leo çeşidinin gerisinde kalmışlardır. $\mathrm{Bu}$ durumun lokasyonlar arasındaki iklim ve toprak özelliklerinin farklılı̆̆ından kaynaklanabileceği gibi genotiplerin hasat dönem veya zamanlamasının farklılığından kaynaklandığı da düşünülmektedir. Çünkü İzmir losayonunda değerlendirilen gazal boynuzu genotipleri 2 yıllık yetiştirme sezonu içerisinde toplam $10 \mathrm{kez}$ biçilmiştir. Buna karşl11k Adana lokasyonunda toplam 6 biçim yapılmıştır.

\section{Tohum verimi}

Tohum verimi açısından, lokasyon, yıl, genotip, y1l $\mathrm{x}$ lokasyon, lokasyon $\mathrm{x}$ genotip ve lokasyon $\mathrm{x}$ genotip $\mathrm{x}$ yıl istatistiksel açıdan önemli bulunmuştur. Adana lokasyonu daha yüksek tohum verimlerine sahip olmuştur 2016 y1l tohum verimleri 2015 y1lı verimlerine göre önemli derecede daha yüksek bulunmuştur (Çizelge 7). Genotipler arasindaki farklar önemli bulunmuş, Leo çeşidinin dışındaki genotipler ilk verim gruplarında yer almışlardır. Kontrol genotipi Populasyon Tokat İzmir lokasyonunda alt verim grubunda yer alırken Adana lokasyonunda ilk verim grubunda yer almıştır. Genotip x lokasyon interaksiyonunun önemli olmasına rağmen çeşit aday1 genotipler her iki lokasyonda da Gaida kontrol çeşidi ile birlikte ilk verim grubunda yer almışlardır. Böylelikle çeşit adayları ve kontrol çeşit Gaida'nın tohum verimlerinin daha stabil olduğu anlaşılmaktadır. Tohum verimleri ortalamaları, Churkova (2007) ve Karadağ ve ark. (2016)'nın bildirişlerinden (28-34,7 kg/da) daha düşüktür, Çınar ve ark. (2016) 'nın bildirişleri $(24,3-28,7 \mathrm{~kg} / \mathrm{da})$ ile uyumludur. Gazal boynuzu bitkisinin ilk yıl gelişimi oldukça yavaştır ve kök sisteminin gelişmesi için bitki besin elementlerinin kullanılması ilk y1l tohum veriminin düşük olmasına neden olabilmektedir (Gençkan, 1992; Churkova, 2007). Bununla beraber büyüme özelliği itibari ile tamamen kararsız bitki olan gazal boynuzunda tohum çatlaması çok yaygın görülen bir özelliktir ve özellikle havadaki nemin \%40'in altına düştüğünde bakla çatlamasının dolayısıyla tohum kaybının olduğu belirtilmiştir (Gençkan, 1992; Açıkgöz, 2001; Hatipoğlu ve Avcıŏlu, 2009). İlk yıl tohum hasadının gecikmiş olması nedeni ile de tohum veriminde bir miktar kayba neden olduğu düşünülebilmektedir.

Genotip x lokasyon x y1l interaksiyonunda ise Leo kontrol çeşit 2015 yılında İzmir lokasyonunda en düşük tohum verimini verirken ETAE-GB-1 çeşit adayı Adana lokasyonunda 2016 yılında en yüksek tohum verimine sahip olmuştur.

Çizelge 7. Gazal boynuzu genotiplerinin tohum verimleri $(\mathrm{kg} / \mathrm{da})$.

Table 7. Seed yields of bird's-foot trefoil genotypes $(\mathrm{kg} / \mathrm{da})$.

\begin{tabular}{|c|c|c|c|c|c|c|c|}
\hline \multirow[t]{2}{*}{ Genotipler / Genotypes } & \multicolumn{3}{|c|}{$\begin{array}{c}\text { İzmir lokasyonu } \\
\text { Izmir location }\end{array}$} & \multicolumn{3}{|c|}{$\begin{array}{c}\text { Adana lokasyonu } \\
\text { Adana location }\end{array}$} & \multirow{2}{*}{$\begin{array}{l}\text { Genel ort. } \\
\text { Gen. mean }\end{array}$} \\
\hline & 2015 & 2016 & Ort./mean & 2015 & 2016 & Ort./mean & \\
\hline ETAE GB-1 & $14,5 \mathrm{fh}$ & $20,7 \mathrm{~cd}$ & $17,6 \mathrm{C}$ & $7,3 \mathrm{j}$ & $45,5 \mathrm{a}$ & $26,4 \mathrm{AB}$ & $22,0 \mathrm{AB}$ \\
\hline ETAE GB-2 & $14,8 \mathrm{eh}$ & $23,7 \mathrm{c}$ & $19,2 \mathrm{C}$ & $12,7 \mathrm{~g}_{1}$ & $42,3 \mathrm{a}$ & $27,5 \mathrm{~A}$ & $23,4 \mathrm{~A}$ \\
\hline Tokat populasyonu & $9,1 \mathrm{ij}$ & $19,1 \mathrm{df}$ & $14,1 \mathrm{D}$ & $12,7 \mathrm{~g}_{1}$ & $43,3 \mathrm{a}$ & $28,0 \mathrm{~A}$ & $21,0 \quad \mathrm{~B}$ \\
\hline Leo & $1,7 \mathrm{k}$ & $16,4 \mathrm{dg}$ & $9,0 \quad \mathrm{E}$ & $9,4 \mathrm{ij}$ & $11,5 \mathrm{hj}$ & $10,4 \quad E$ & $9,7 \quad \mathrm{C}$ \\
\hline Gaida & $20,1 \mathrm{~cd}$ & 19,3 ce & $19,7 \mathrm{C}$ & $9,4 \mathrm{ij}$ & $37,4 \mathrm{~b}$ & 23,4 B & $21,5 \mathrm{AB}$ \\
\hline Lokasyon / Location & $* * *$ & & $15,9 \mathrm{~b}$ & & & $23,1 \mathrm{a}$ & \\
\hline Y1l / Year & $11,2 \mathrm{~b}$ & 27,9 a & & & & & \\
\hline Genotip / Genotype & $* * *$ & & & & & & \\
\hline Genotip x Lokasyon & $12,0 \mathrm{c}$ & $19,8 \mathrm{~b}$ & & $10,3 \mathrm{c}$ & $36,0 \mathrm{a}$ & & \\
\hline Yil x Lok. / Year x Loc. & $* * *$ & & & & & & \\
\hline Yil x Lok. x Gen/Year x Lo..x Gen. & $* * *$ & & & & & & \\
\hline \multirow{2}{*}{\multicolumn{8}{|c|}{$\begin{array}{ll}\text { LSD (0,05): } & \text { Genotip / Genotype: 2,1; Lokasyon / Location: 1,43; Y1l / Year: 5,06 } \\
& \text { Genotip.x Lokasyon / Genotype x Location: 3,19; Y1l x Lokasyon / Year x Location: 5,25 } \\
& \text { Y1l x Lokasyon x Genotip / Year x Location x Genotype: 4,44 }\end{array}$}} \\
\hline $\mathrm{CV}(\%)$ & & & & & & & 16,34 \\
\hline
\end{tabular}




\section{Çimlenme oranları (\%)}

Yapılan değerlendirmede; y1l, genotip, lokasyon, $\mathrm{y} 1 \mathrm{x}$ lokasyon, genotip $\mathrm{x}$ lokasyon ve $\mathrm{y} 1 \mathrm{l}$ lokasyon $\mathrm{x}$ genotip interaksiyonları istatistiki olarak önemli bulunmuştur. Adana lokasyonu $\% 67,6$ çimlenme oranı ile İzmir lokasyonundan $(\% 59,2)$ daha fazla çimlenme yüzdesine sahip olmuştur. 2015 y1lı 67,7 çimlenme yüzdesine sahip olurken, 2016 yılında çimlenme yüzdesi 59,1 olarak daha düşük oluşmuştur. Genotipler arasındaki farklar önemli bulunmuştur. Bununla beraber genotip $\mathrm{x}$ lokasyon interaksiyonu da önemli olarak saptanmıştır. İzmir lokasyonunda Leo kontrol çeşidi son grubu oluştururken, diğer çeşitler yakın çimlenme oranları ile benzer gruplarda yer almışlardır. Adana lokasyonunda ise kontrol Tokat populasyonu ilk grupta tek başına yer alırken diğer genotiplerin hepsi siralamada ikinci grupta yer almışlardır (Çizelge 8).

Çimlenme oranlarındaki düşüklüğün nedenleri arasında Lotus corniculatus' un tohumlarında önemli oranda sert tohumluluğun olduğu ve iklimsel olaylardan etkilendiği farklı lokasyonlarda yapılan çalışmalarla da bildirilmiş̧ir (Gençkan, 1992; Hatipoğlu ve Avcıoğlu, 2009).

\section{Bin tane ağırlıkları}

1000 tane ağırlığı açısından yapılan değerlendirmede; lokasyon önemsiz, yıl, genotip, $\mathrm{y} 1 \mathrm{l} \mathrm{x}$ lokasyon, genotip $\mathrm{x}$ lokasyon ve $\mathrm{y} 1 \mathrm{l} \mathrm{x}$ lokasyon $\mathrm{x}$ genotip interaksiyonları istatistiki olarak önemli bulunmuştur. 2016 y1lı bin tane ağırlığı (1,20 g) 2015 yılına göre $(1,11 \mathrm{~g})$ daha büyük bulunmuștur. Genotipler arasındaki farklar ve genotip $\mathrm{x}$ lokasyon interaksiyonu önemli bulunmasına rağmen aday genotipler her iki lokasyonda da kontrol çeşit Gaida ile ilk sıralarda yer almışlardır (Çizelge 9).

Bin tane ağırlıkları açısından bulgularımız Karadağ ve ark. (2016) (1,15-1,17 g); Gençkan (1992) (11,3g); Hatipoğlu ve Avcioğlu (2009) (1,2-1,4 g) ile uyumlu; Çınar ve ark. (2016)'nın sonuçlarından $(0,95-1,05 \mathrm{~g})$ daha yüksek bulunmuştur. Bologno ve ark. (1996)'nın ifade ettiği bin tane ağırlıkları $(1,38-1,52 \mathrm{~g})$ değerleri ise deneme bulgularımızdan daha yüksektir. Gazal boynuzu genotipleri farklı çevre koşullarında farklı verim değerleri aldıkları gibi çeşitler arasında bin tane ağırlıkları açısından da farklılıklar olabilmektedir.

Çizelge 8. Gazal boynuzu genotiplerinin çimlenme oranları (\%).

Table 8. Germination rates of bird's-foot trefoil genotypes (\%).

\begin{tabular}{|c|c|c|c|c|c|c|c|c|}
\hline \multirow[t]{2}{*}{ Genotipler / Genotypes } & \multicolumn{4}{|c|}{$\begin{array}{l}\text { İzmir lokasyonu } \\
\text { Izmir location }\end{array}$} & \multicolumn{3}{|c|}{$\begin{array}{c}\text { Adana lokasyonu } \\
\text { Adana location }\end{array}$} & \multirow{2}{*}{$\begin{array}{l}\text { Genel ort. } \\
\text { Gen. mean }\end{array}$} \\
\hline & & 2015 & 2016 & Ort./mean & 2015 & 2016 & Ort./mean & \\
\hline ETAE GB-1 & & $58,5 \mathrm{df}$ & 64,5 ce & $61,5 \mathrm{C}$ & $73,7 \mathrm{ab}$ & $60,7 \mathrm{cf}$ & $67,2 \mathrm{BC}$ & $64,3 \mathrm{~A}$ \\
\hline ETAE GB-2 & & 65,5 be & $62,7 \mathrm{cf}$ & $64,1 \mathrm{C}$ & $79,2 \mathrm{a}$ & $55,0 \mathrm{fg}$ & $67,1 \mathrm{BC}$ & $65,6 \mathrm{~A}$ \\
\hline Tokat populasyonu & & $55,5 \mathrm{f}$ & $68,5 \mathrm{bc}$ & $62,0 \mathrm{C}$ & $81,0 \mathrm{a}$ & $66,7 \mathrm{bd}$ & $73,8 \mathrm{~A}$ & $67,9 \mathrm{~A}$ \\
\hline Leo & & $38,0 \quad 1$ & $47,0 \mathrm{gh}$ & $42,5 \quad \mathrm{D}$ & 78,7 a & 45,7 h1 & $62,2 \mathrm{BC}$ & 52,3 B \\
\hline Gaida & & $68,5 \mathrm{bc}$ & $63,2 \mathrm{cf}$ & $65,8 \mathrm{BC}$ & $78,2 \mathrm{a}$ & 57,5 ef & $67,8 \mathrm{~B}$ & $66,8 \mathrm{~A}$ \\
\hline Lokasyon / Location & $* * *$ & & & $59,2 \mathrm{~b}$ & & & $67,6 \mathrm{a}$ & \\
\hline Yil / Year & $* * *$ & $67,7 \mathrm{a}$ & $59,1 \mathrm{~b}$ & & & & & \\
\hline Genotip / Genotype & $* * *$ & & & & & & & \\
\hline Genotip x Lokasyon & $* * *$ & $57,2 \mathrm{c}$ & $61,2 \mathrm{~b}$ & & $78,2 \mathrm{a}$ & $57,1 \mathrm{c}$ & & \\
\hline Y1l x Lok. / Year x Loc. & $* * *$ & & & & & & & \\
\hline Yil x Lok. x Gen/Year x Lo..x Gen. & * & & & & & & & \\
\hline \multicolumn{9}{|c|}{$\begin{array}{ll}\text { LSD (0,05): } & \text { Genotip / Genotype 8,46; Lokasyon / Location: 2,58; Y11 / Year: 5,35 } \\
& \text { Genotip.x Lokasyon / Genotype x Location: 5,78; Y1l x Lokasyon / Year x Location: 5,93 } \\
& \text { Y1l x Lokasyon x Genotip / Year x Location x Genotype: 7,78 } \\
\end{array}$} \\
\hline CV (\%) & & & & & & & & 9,14 \\
\hline
\end{tabular}


Christiansen-Weniger F., V. Horn, and L. Jung. 1979. Bodenschutz-und Ackerbauliche Massnahmen zur Erhaltung gefaerdeter Türkischer Böden sowie zur Steigerung des Futterpflanzenbaues und der Tierproduktion. Giessen.

Ellis, R. H., T. D. Hong, and E. H. Roberts. 1985. Handbook of seed Technology for Genebanks. Vol. 2. Compendium of Specific Germination Information and Test Recommendations. International Board for Plant Genetic Resources. Rome. Italy.

Frame, J., J. F. L. Charlton, and A. S. Laidlaw. 1998 Temperate Forage Legumes. CAB International. Wallingtonford. ISBN 0851992145.

Gençkan, M. S. 1992. Yembitkileri Tarımı (II. Basım) Ege Üniversitesi Ziraat Fakültesi Yayınları No: 467, s. 180-184, Bornova-İzmir.

Hatipoğlu, R. ve R. Avcığlu. 2009. Gazalboynuzu Türleri (Lotus sp.), Tarım ve Köyişleri Bakanlığı, Tarımsal Üretim ve Geliştirme Genel Müdürlüğü Baklagil Yem bitkileri Cilt II (Ed. R. Avcıoğlu, R., Hatipoğlu, ve Y. Karadağ) s. 387-399.

Karadağ, Y., S. Çınar, T. Taşyürek, S. Gökalp, M. Özkurt, 2016. Tokat- Kazova Ekolojik koşullarında bazı çok y1llik yem bitkilerinin verim ve kalitelerinin belirlenmesi. Tarla Bitkileri Merkez Araştırma Ens. Dergisi (Özel say1) 25: 206-212.

Knowless, R. P. 1977. Recurrent mass selection for improved seed yields in intermediate wheatgrass. Crop Science 17: 51-54.

Marley, C. L., R. Fychan, R., Jones, 2006. Yield, persistency and chemical composition of Lotus species and varieties (birdsfoot trefoil and greater birdsfoot trefoil) when harvested for silage in the UK. Grass and Forage Science 61 (2): 134-145.

Marshall, A. H., and P. W. Wilkins. 2003. Improved seed yield in perennial ryegrass (Lolium perenne L.) from two generations of phenotypic selection. Euphytica 133: 233-241.
Özkan, U. ve N. Ş. Demirbağ. 2016. Türkiye'de Kaliteli Kaba Yem Kaynaklarını Mevcut Durumu. Türk Bilimsel Derlemeler Dergisi 9: 23-27.

Poehlman, J. M. 1987. Breeding Field Crops. The Avi Publishing Company, (Third edition). Inc. Westport. Connecticut, USA.

Poehlman, J. M., and D. A. Sleeper. 1995. Breeding Field Crops. Fourth Edition. Iowa State Univ Press. Ames.

Sabanc1, C. O. ve M. Tosun. 2009. Yem bitkileri Islahı. Yem bitkileri Genel Bölüm Cilt I., 214-240. Editörler: R. Avcıŏlu, R. Hatipoğlu R., Y. Karadağ. T.C. Tarım ve Köyişleri Bakanlığı Tarımsal Üretim ve Geliştirme Genel Müdürlügü. İzmir - Emre Basımevi.

Sardaro, M. L. S., M. Atallah. E. Tavakol, .L. Russi, and E. Porceddu. 2008. Diversity for AFLP and SSR in natural populations of Lotus corniculatus L. Crop Science 48: 1080-1089.

Soya,H., R. Avcıŏlu, H. Geren, B. Kır, G. Demiroğlu, T. Kavut. 2005. Türkiye'de kullanılan çim ve yembitkileri tohumlarının bazı fiziksel özellikleri üzerinde araştırmalar. Türkiye II. Tohumculuk Kongresi, 9-11 Kasım 2005. s. 242-247, Adana.

Steel, R. G. D., and J. H. Torrie. 1980. Principles and Procedures of Statistics. Second Ed. McGraw-Hill Book Company Inc., New York.

Van Soest, P. J., J. D. Robertson, and B. A. Lewis. 1991. "Methods for dietary fibre. neutral detergent fibre and non-starch polysaccharides in relation to animal Nutrition”. J. Dairy Science 74: 3583-3597.

Yurtsever, N. 1984. Deneysel Istatistik Metotları. Köy Hizmetleri Toprak ve Gübre Arş. Enst. Müdürlügüü Yavınları Genel Yayın No. 121 Ankara. 